\title{
Analisis Kesehatan Mental dalam Meningakatkan Imunitas Tubuh untuk Menghadapi COVID-19 Kota Kisaran Barat, Kabupaten Asahan, Sumatera Utara
}

\author{
Putri Gunti Isnaini ${ }^{* 1}$, Nuriah ${ }^{2}$, Alda Zulaika ${ }^{3}$, Nondang Mey Rina Sari Siregar ${ }^{4}$, Okky Anas \\ Azizy $^{5}$, Renaldy Alifka Rizky ${ }^{6}$, Meilani $^{7}$ \\ 1,2,3,4,5,6Prodi Bimbingan Penyuluhan Islam, Fakultas Dakwah dan Komunikasi, Universitas Islam \\ Negeri Sumatera Utara, Indonesia \\ Email: 1 putriguntiis@gmail.com, ${ }^{2}$ nnuriyah450@gmail.com, ${ }^{3}$ aldazulaika923@gmail.com, \\ ${ }^{4}$ nondangmeyrina@gmail.com, ${ }^{5}$ Okkyanas1@gmail.com, ${ }^{6}$ renaldyrizky026@gmail.com, \\ ${ }^{7}$ meilanipasaribu1@gmail.com
}

\begin{abstract}
Abstrak
Pada masa COVID-19 seperti sekarang ini semua kegiatan harus dibatasi dan berjarak demi mencegah penularan virus ini. Pada penelitian ini akan dibahas mengenai analisis kesehatan mental dalam meningakatkan imunitas tubuh untuk menghadapi COVID-19. Dalam rangka menghadapi penyebaran virus corona ini, semua masyarakat dituntut untuk selalu meningkatkan imunitas tubuhnya selama masa pandemi, dengan Menerapkan pola hidup sehat dan pola makan yang sehat dan bergizi dan hal ini harus dilakukan agar terhindarnya dari paparan COVID19. Penelitian ini menggunakan pendekatan kualitatif dan studi lapngan dan pengumpulan data melalui observasi, wawancara dan dokumentasi. Sementara, teknik analisis data pada penelitian menggunakan analisis wacana dan diskusi secara online maupun offline melalui group whatsapp dan pertemuan terbatas. Informan dari penelitian ini adalah Bidan, dan masyarakat. Hasil dari penelitian ini menujukkan bahwa dimasa pandemi COVID-19 ini masyarakat dihimbau bukan hanya mematuhi protokol kesehatan, tetapi juga dalam meningkatkan imunitas tubuh seperti mengatur pola hidup dan pola makan dalam mehdapai COVID-19. Sistem imun tubuh merupakan bagian tubuh yang sangat penting yang membantu menjaga tubuh tetap sehat dan mampu mendukung berbagai aktivitas. Ketika sistem kekebalan tubuh kuat, ia dapat bertahan melawan penyebab penyakit dalam tubuh. Kesehatan semakin penting dan menjadi prioritas, salah satunya melindungi tubuh dari berbagai bakteri dan virus COVID19 ini.
\end{abstract}

Kata Kunci: COVID-19, Imunitas, Kesehatan Mental

\begin{abstract}
During this time of COVID-19, all activities must be limited and distanced to prevent the transmission of this virus. In this study, we will discuss the analysis of mental health in increasing the body's immunity to deal with COVID19. In order to deal with the spread of the corona virus, all people are required to always increase their body immunity during the pandemic, by implementing a healthy lifestyle and a healthy and nutritious diet and this must be done to avoid exposure to COVID-19. This study uses a qualitative approach and field studies and data collection through observation, interviews and documentation. Meanwhile, the data analysis technique in the study used discourse analysis and discussions online and offline through WhatsApp groups and limited meetings. The informants of this study were midwives, and the community. The results of this study show that during the COVID19 pandemic, people are encouraged not only to comply with health protocols, but also to increase body immunity such as regulating lifestyle and eating patterns in dealing with COVID-19. The immune system is a very important part of the body that helps keep the body healthy and able to support various activities. When the immune system is strong, it can defend against disease-causing agents in the body. Health is increasingly important and becomes a priority, one of which is protecting the body from various bacteria and the COVID-19 virus.
\end{abstract}

Keywords: COVID-19, Imminity, Mental Healty

\section{PENDAHULUAN}

Kondisi COVID-19 ini memberikan dampak yang luar biasa bagi masyarakat dan juga berdampak 
luar biasa bagi kesehatan mental masyarakat, dan kondisi ini telah menjadi suatu penyebab baru munculnya stres, karena ketidakpastian akan berakhirnya masa pandemi, social distancing, isolasi, stigma dan diskriminasi terhadap penderita, hingga kesulitan ekonomi memiliki dampak terhadap kesehatan mental masyarakat sekitar. Hal ini memiliki perubahan-perubahan dan menjadi suatu tantang bagi masyarakat itu sendiri.

Kondisi merebaknya COVID-19 ini tentunya berdampak pada semua sisi kehidupan dan biasanya sangat dirasakan oleh semua individu, terutama mereka yang hidupnya dalam kondisi menyusahkan (kurang beruntung). Individu yang terkena infeksi virus corona (SARS-CoV-2) berpotensi menularkan virus tersebut ke orang lain, dan pada beberapa masyarakat harus dirawat di rumah sakit karena kondisi yang serius. Ketika pandemi menyebar, tekanan yang besar pada sistem kesehatan dan adanya lockdown menyebabkan akses terhadap informasi dan pelayanan kesehatan semakin terbatas, sehingga berdampak pada kesehatan mental (Akhmad Mustofa, 2020).

Kesehatan mental merupakan kondisi seseorang yang memungkinkannya berkembang dan berfungsi secara optimal serta selaras dengan perkembangan orang lain (Fakhriyani, 2019). Pieper dan Uden mengatakan bahwa kesehatan mental adalah suatu keadaan dimana seseorang tidak merasa bersalah pada dirinya sendiri, menilai dirinya secara realistis dan dapat menerima kekurangan dan kelemahannya, mampu menghadapi masalah dalam hidupnya, merasakan kepuasan dalam kehidupan sosialnya dan mengalami kebahagiaan dalam hidupnya (Dewi, 2012).

Dalam rangka menghadapi penyebaran virus corona ini, semua masyarakat dituntut untuk selalu meningkatkan imunitas tubuhnya selama masa pandemi. Yaitu dengan cara menerapkan pola hidup sehat seperti olahraga secara teratur, konsumsi makanan bergizi, tidur yang cukup, kelola stress, berjemur, menjaga kebersihan makanan dan kebersihan diri serta lingkungan. Meningkatkan imunitas tubuh selama masa pandemi sangat penting untuk menghindari dari paparan virus corona. Sistem imun tubuh merupakan bagian tubuh yang sangat penting yang membantu menjaga tubuh tetap sehat dan mampu mendukung berbagai aktivitas. Ketika sistem kekebalan tubuh kuat, ia dapat bertahan melawan penyebab penyakit dalam tubuh. Kesehatan semakin penting dan menjadi prioritas, salah satunya melindungi tubuh dari berbagai bakteri dan virus COVID-19 ini. Maka peneliti tertarik untuk mengkaji lebih dalam mengenai "Analisis Kesehatan Mental Dalam Meningakatkan Imunitas Tubuh Untuk Menghadapi COVID-19 Kota Kisaran Barat, Kabupaten Asahan, Sumatera Utara"

\section{METODE PENELITIAN}

Penelitian ini memfokuskan tentang analisis kesehatan mental dalam meningakatkan imunitas tubuh untuk menghadapi COVID-19. Penelitian ini dilakukan di Kota Kisaran, Kabupaten Asahan, Kecamatan Kisaran Barat tepatnya di Jl. Ikan Baung, Gg. Nyiur Lk.II pada bulan Oktober 2021. Tipe penelitian ini menggunakan pendekatan kualitatif dan studi lapangan. Data yang dikumpulkan melalui observasi, wawancara dan dokumentasi Sampel dari penelitian ini diambil 2 informan terdiri dari Bidan dan masyarakat Sekitar. Studi Lapangan yaitu melakukan wawancara, yaitu proses pengumpulan data melalui tanya jawab dan diskusi kepada pihak responden dan informan dengan cara melakukan interaksi secara langsung dengan pihak-pihak yang bersangkutan mengenai permasalahan yang diangkat. Teknik analisis data pada penelitian menggunakan analisis wacana dan diskusi secara online maupun offline melalui group WhatsApp dan pertemuan terbatas.

\section{HASIL DAN PEMBAHASAN}

Kegiatan penelitian ini dilakukan untuk melihat bagaimana upaya peningkatan masyarakat Kisaran Barat khususnya di Jl. Ikan Baung Gg. Nyiur, Lk.II dalam meningkatkan imunitas tubuh di masa pandemi COVID-19. Dengan adanya tingkat yang terpapar virus corona ini masyarakat kisaran barat sangat sadar akan perlunya menjaga pola hidup bersih dan sehat (PHBS) serta mematuhi protokol kesehatan seperti penggunaan hand sanitizer, mencuci tangan dengan baik dan benar, dan menggunakan masker saat keluar rumah serta aktif mengikuti vaksinasi yang diberikan oleh pemerintah setempat untuk mencegah dan mengurangi jumlah penderita COVID-19 di Kota Kisara Barat Kabupaten Asahan.

Dalam rangka menghadapi penyebaran virus corona ini, persiapan fisik sangat dijaga seperi kekebalan imunitas tubuh. Menjaga kebugaran jasmani selama pandemi penting untuk menghindari 
segala jenis penyakit. Sistem imun tubuh merupakan bagian tubuh yang sangat penting yang membantu menjaga tubuh tetap sehat dan mampu mendukung berbagai aktivitas. Ketika sistem kekebalan tubuh kuat, ia dapat bertahan melawan penyebab penyakit dalam tubuh. Kesehatan semakin penting dan menjadi prioritas, salah satunya melindungi tubuh dari berbagai bakteri dan virus. Stres, kurang istirahat, dan tidak cukup berolahraga dapat menyebabkan penurunan sistem kekebalan tubuh.

\subsection{Pengertian Imunitas Tubuh}

Imunitas adalah semua peristiwa pertahanan tubuh terhadap serangan benda asing (kuman, penyakit kuman dan bakteri), sistem kekebalan tubuh juga merupakan kemampuan tubuh untuk melawan infeksi meniadakan kerja toksin dan faktor virulensi lainnya yang bersifat antigenik dan imunogenik (Wardhani, 2019).

Adapun jenis-jenis sistem imun dalam tubuh diantaranya:

1. Sistem Imun Non-Spesifik

Sistem ini merupakan sistem pertahanan yang terjadi secara alamiah dan tidak dipengaruhi secara intrinsik oleh kontak dengan agen infeksi sebelumnya. Komponen pertahanan ini berfungsi sebagai garis pertahanan utama dan menahan sebagian besar patogen potensial beberapa waktu belakangan ini menjadi perkembangan yang jelas seperti perlindungan fisik atau mekanis, resistensi biokimia, perlindungan dan resistensi humoral.

2. Sistem Imun Spesifik

Sistem imun spesifik merupakan sistem imun didapat karena dapat mengingat agen infeksi tertentu sehingga dapat mencegah terjadinya penyakit di kemudian hari. Adapun sistem imun spesifik ini yaitu sistem imun, spesifik humoral, dan sistem imun seluler.

\subsection{Upaya Atau Cara Yang Dilakukan Untuk Meningkatkan Imunitas Tubuh}

Dalam rangka menghadapi penyebaran virus corona ini adapun upaya atau cara yang dialkukan untuk meningkatkan imunitas tubuh diantarnya:

1. Rajin Berolahraga

Dengan rajin berolahrga mampu mengeluarkan bakteri dari paru-paru dan saluran pernapasan. Selain itu, rajin berolahraga berdampak positif bagi kesehatan mental karena olahraga terbukti dapat meringankan stres, memperbaiki suasana hati, meningkatkan rasa percaya diri, hingga meningkatkan daya tahan tubuh. Sediakan waktu untuk berolahraga setiap hari selama minimal 30 menit (Adrian, 2021).

2. Konsumsi Makanan Bergizi dan Seimbang

Semakin banyak mengkonsumsi makan yang bergizi didalam tubuh seseorang, seperti mengkonsusmsi buah, sayuran, ikan, telur, susu, biji-bijian, serta kacang-kacangan, dan lain-lain maka hal ini memperkuat daya tahan tubuh seseorang selama masa pandemi (Adrian, 2021).

3. Tidur Yang Cukup

Dengan tidur yang cukup dan nyenyak dapat menjaga, bahkan memperkuat daya tahan tubuh. Sebaliknya, kurang tidur dapat membuat tubuh rentan terkena penyakit. Dan hal ini bagus dalam situasi COVID-19 ini dan waktu tidur yang cukup sekitar 7-9 jam per hari. (Adrian, 2021).

4. Kelola Stres

Dalam masa pandemi COVID-19 ini kelola stres sangat di perlukan karena, jika stres yang berkepanjangan dapat menurunkan daya tahan tubuh.

5. Berjemur

Di masa pandemi ini berjemur sangat penting dilakukan sebab, dengan bejemur di pagi hari pada pukul 08:00-11:00, selama 10-15 menit dan sebanyak 2-3 kali dalam seminggu. Hal ini kan meningkatkan produksi vitamin D dan daya tahan tubuh (Adrian, 2021).

Dalam wawancara dan diskusi bersama Ibu Bidan Hartini S.tr.Kep, beliau mengatakan bahwa adanya social distancing berdampak pada kesehatan psikologis seseorang, karena ada nya keterbatasan seseorang dalam beraktivitas dan orang-orang sulit berintraksi dengan yang lain, ini akan meningkatkan kesepian pada diri seseorang dan akan memicu seseorang cemas dan berakibat stres atau depresi. Untuk itu semua masyarakat harus bisa memperkuat daya tahan tubuh agar tehindar dari paparan virus corona 
ini, dengan cara berolahrga secara rutin, seperti bersepeda atau jalan pagi, dan juga selalu menjaga pola makan yang sehat agar daya tahan tubuh bisa terhindar dari bakteri dan jangan memakan makanan sembarang atau makanan yang beli diluar yang belum tau highenis atau tidaknya makanan tersebut, hal ini akan memicu turunnya daya tahan tubuh, kemudian rajin berjemur di pagi hari minimal seminngu dua kali selama 15 menit, dan rajin meminum vitamin atau minuman herbal yang bisa dibuat dirumah serta selalu mematuhi prokol kesehatan, dan juga melakukan vaksinasi yang di himbau oleh pemerintah agar bisa mencegah dari paparan virus corona.

Dalam wawancara Bapak Hartono Lubis selaku kepala desa Jl. Ikan Baung Gg. Nyiur, Lk.II, beliau mengatakan bahwa, saya dan keluarga saya selama pandemi COVID-19 ini selalu antisipasi yaitu dengan cara selalu memtahui protokol kesehtan seperti, rajin mencuci tangan, memakai masker jika keluar rumah, dan hal yang kami lakukan sehari-hari selama pandemi yaitu saya selalu mengajak istri dan anak saya untuk berolahrga pagi disekitar rumah atau bersepeda jika bosan, dan juga istri saya selalu memasak makanan yang sehat dan kami selalu meminum-minuman herbal seperti jamu atau pun mengkonsumsi vitamin, hal ini kami lakukan agar dalam memeprkuat daya tahan tubuh dalam mengadapai pandemi ini. Dan juga pada malam hari kami sekelurga berbincang-bincang atau berdiskusi tentang masalah hari ini atau ada kendala apa yang dihapi hari ini, dan hal ini kami lakukan agar jika ada masalah dapat kami selesaikan bersama-sama dan hal ini tidak berdampak stres pada keluarga kami dan kegiatan yang kami lakukan bisa dicontoh oleh masyarkat sekitar. Dan hal ini terbukti banyak masyarakat Jl. Ikan Baung Gg. Nyiur, LK.II telah wasapada dan selalu menjaga pola hidup sehat tehindar dari paparan virus corona, walapun ada beberapa warga yang kurang sadar pentingya menjaga pola hidup sehat selama masa pandemi.

Dari hasil penelitian yang dilakukan menunjukkan bahwa banyak masyakarkat yang telah sadar dalam pentingnya menjaga pola hidup sehat dan pentingnya meningkatkan imunitas dalam diri seseorang selama masa pandemi, walapun beberapa diantara mereka kurang peduli akan bahayanya COVID-19 ini, jika tidak menanamkan pola hidup sehat dalam dirinya maka hal ini akan mimicu bakteri atau virus itu datang ketubuh kita.

\section{KESIMPULAN}

Dalam pandemi COVID-19 yang sedang melanda saat ini, sangat penting untuk meningkatkan imunitas tubuh dengan pola hidup sehat seperti rajin berolahrga, mengkonsumis makanan-makanan bergizi, berjemur, tidur yang cukup dan mengkolala stres dalam diri kita, sebab jika kita stres itu akan berdampak pada ganguan mental. Untuk itu masyakat harus sadar akan pentingnya menjaga pola hidup sehatn dan meningkatkan imunitas tubuh selama pandemi COVID-19 ini, dengan kuat nya imunitas tubuh seseorang maka bakteri atau virus yang datang akan lemah dengan imunitas tubuh yang kuat.

\section{DAFTAR PUSTAKA}

Adrian, d. K (2021). 5 Cara Meningkatkan Daya Tahan Tubuh di Masa Pandemi yang Ampuh. Alodokter, p. 1.

Akhmad Mustofa, N. S (2020). Meningkatkan Imunitas Tubuh Dalam Menghadapi Pandemi COVID19 Di Karangtaruna Keduppit, Sidoharjo, Wonogiri, Jawa Tengah. Jurnal Pengabdian Masyarakat Berkemajuan, 332.

Dewi, K. S (2012). Buku Ajar Kesehatan Mental. Semarang: UPT UNDIP Press Semarang.

Fakhriyani, D. V (2019). Kesehatan Mental. Jawa Timur: Duta Media Publishing.

Wardhani, S. P (2019). Intisari Biologi Dasar. Yogyakarta: Diandra kreatif. 